\title{
Preliminary studies: the effect of temperature on the accessory gland in Drosophila melanogaster
}

\author{
Abolhasan Rezaei ${ }^{1,2} *$ MS Krishna ${ }^{1} *$ H.T. Santhosh ${ }^{1}$ and S. C. Jayaramu ${ }^{1}$ \\ *1: Drosophila Stock Centre, Department of Studies in Zoology, University of Mysore, \\ Manasagangotri, Mysore 570006, Karnataka State, India \\ 2: Department of Genetics-School of Basic Science, Tonekabon Branch, Islamic Azad \\ University, Tonekabon, Iran. \\ 1- a.rezaei@tonekaboniau.ac.ir 2- drosokrish@gmail.com 3- $\underline{\text { santhoshuom@gmail.com }}$
}

\section{ABSTRACT}

The accessory gland has a simple structure composed of a single layer of a cells surrounding a lumen that is in turn surrounded by a muscle sheath. It synthesizes a proteins, carbohydrates and lipids which are transferred at the time of mating between male to the mating female. In this study we have determined the number of cells, cell size and gland size in male Drosophila melanogaster, unmated male flies of 2-3 day old were used the exposed to three temperatures, cold $\left(15^{\circ} \mathrm{C}\right)$, middle $\left(22^{\circ} \mathrm{C}\right)$ and high $\left(29^{\circ} \mathrm{C}\right)$ temperature. The results showed, cell size in cold temperature was smaller than middle and high temperature and between three temperatures results of ANOVA and correlation coefficient were significant, $p$ value $<0.01$ (cold $>$ middle $>$ high). Results of cell number in cold, middle and high temperature by ANOVA variation and correlation coefficient was significant, the mean value of cell number in high temperature more than low and middle temperature respectively (High $>$ cold $>$ middle). Regarding, gland size, the mean value also, in high temperature condition bigger than middle temperature. The results of ANOVA variation and correlation coefficient were significant. [Our main aim is to show the effect of temperature on the reproductive system, especially on the male accessory gland in Drosophila including, structure of gland of cell size and cell number, that changed when flies were exposed to different temperature].

Keywords: Accessory gland, cell size, cell number, Drosophila melanogaster

\section{INTRODUCTION}

Accessory gland proteins (Acps) induce a variety of physiological, behavioral and reproductive changes, when transferred to the female. Between 25 to 150 Acps were initially thought to be transferred to the female during mating (Coulthart and Singh, 1988; IngmanBaker and Candido, 1980; Schmidt, 1985; Whalen and Wilson, 1986; Wolfner et al., 1997).These proteins are produced in the gland of Drosophila melanogaster, that size of gland, cell number and cell size are necessary for the secretion, quality and quantity of proteins.

Kalb et al., 1993; Xue and Noll, 2000, proposed, that males lacking Acps in males indicate the reproductive performance. Acps, in flies play an important function on the female fitness traits, including, egg laying, egg hatchability, larval viability and offspring produced also in males they cause on increase in sperm storage, sperm motility and sperms used (reviewed in Chapman and Davies, 2004; Wolfner, 2002). We started the hypothesis that the growth and development of the gland size, cell number and cell size of the glands are the most important factors in determining the reproductive performance in mature males and females. Accessory gland size is necessary for the male reproductive success (Bangham et al., 2002). And that accessory gland size has a strong effect on the rate of spermatophores produced, that larger accessory glands are a determinant of male reproductive success in flies, with high rates of mating and males possessing larger accessory glands are at an advantage, accessory gland products are critical for mating success, and it is likely that accessory gland size, cell 
size and cell number has a strong effect on the rate at which spermatophores are produced. Recently, in Drosophila it was reported that sperm production is related to development of accessory glands (Xue and Noll, 2000). In relation, temperature is the most probable selective factor making it important for experiments on development to accessory glands. Here, we aimed, effect of temperatures on the accessory gland elements. In this regards increased temperatures at the cause the growing at gland elements including cell size, cell number and gland size in $D$. melanogaster. However the our results showed temperature has a positive effect on the function of accessory gland elements. Also it more research on the other reproductive factors including, female fecundity and fertility are needed finding sure results on the male reproductive performance in $D$. melanogaster.

\section{MATERIALS AND METHODS}

\section{Drosophila melanogaster stocks and maintenance:}

The flies were obtained from the National Drosophila Stock Centre, Department of Zoology (UOM)-India. These flies were used for studies on the effects of temperature on the accessory gland. The flies were cultured and using wheat cream agar medium at $70 \%$ humidity and were exposure on to cold $\left(15^{\circ} \mathrm{C}\right)$ middle $\left(22^{\circ} \mathrm{C}\right)$ and high $\left(29^{\circ} \mathrm{C}\right)$ temperatures. Twenty quarter milk bottle $(250 \mathrm{ml})$ were maintained using 12:12 hour light /dark cycle. The flies were kept in vial by separating male and female and until age the required for the experiment.

\section{Influence of temperature on the male reproductive system:}

In the present study, we have used the effect of temperature on the among of cell size, cell number and also gland size, the these temperature, include, $15^{\circ} \mathrm{C}, 22^{\circ} \mathrm{C}$ and $29{ }^{\circ} \mathrm{C}$, belong to middle and high temperature respectively. The male and female flies were aged for $2-3$ days and 5-6 days respectively. For studies of effect of different temperature on the male reproductive glands, the flies after eclosion from eggs, immediately were separated, males and females were placed in new vials. These male flies were immediately kept in incubator for three temperatures $\left(15,22\right.$ and $\left.29^{\circ} \mathrm{C}\right)$ until unmated males were aged 2- 3 days.

\section{Determination of cell number of gland:}

In this study we investigated on the cell number of glands in Drosophila melanogaster, cell number of the basal layer were observed under loop, the glands were dissected out from males of 2-3 days old, there were exposed to three temperature condition (cold, middle and high temperatures). The glands were treatment with solutions including, medium A (Ashburner 1970) (0.03 sodium phosphate buffer(PH. 6.8), 0.298 gm-0.04M KCl (BDH India), 0.064 gm-0.01M NaCl (BDH India), 0.333gm-0.03M, CaCl2(BDH-India), 0.427gm$0.021 \mathrm{M} \mathrm{MgCl} 2$ (BDH India), after chemicals, were measured out and were dissolved and made up to $100 \mathrm{ml}$ with double distilled water, these glands immediately transferred to $1 \mathrm{~N}$ $\mathrm{HCl}$ for $5 \mathrm{~min}$ and stained for $20 \mathrm{~min}$ in 3\% lacto aceto-orcein. The glands were squashed between a slide and a cover ship is placed on if so as to spread the cells in a single layer. The cells of gland were counted and average was recorded.

\section{Determination of cell size index:}

The cell size of the gland estimated for cell number method, after the treatment of the gland with the solutions, the cells were measured with a magnification of 40x with the help of camera Lucida. The cells length and breadth were measured for fifty replicates. In finally the cell size was computed of compared by SPSS software.

\section{Determination gland size index:}

The gland size index such as cell number and cell size were computed for young male in three temperature conditions. For the sake of convenience we divided the whole area into smaller areas consisting of triangles, trapeziums and rectangles and accordingly the areas were marked. The areas of these geometrical forms were calculated individually trough well known mathematical formulae. The sum of these areas was considered as the size of the gland $\left(\mathrm{cm}^{2}\right)$. Actual area of the gland in the fly was calculated by dividing these values with the magnification. The data were calculated by SPSS software. 


\section{Statistical analysis:}

The percent of male reproductive accessory glands performance such as , cell size, cell number and gland size were analyzed by an SPSS software program (version 10.1) with the average cell number, cell size and gland size of young male flies in dependent of exposure of cold, middle and high temperatures in the fifty replicates. These parameters were computed by mean value, one way ANOVA variation, and correlation index.

\section{RESULTS}

\section{Influence of different temperatures on the accessory gland experiments:}

In Drosophila melanogaster, 25 to 150 accessory gland proteins are a major part of seminal fluid are essential for the storage and utilization of sperm that was used for increase in fecundity and fertility in females. The temperature is important for function of accessory gland in Drosophila melanogaster. In this study unmated males of 2-3 days old were exposed to different temperature the results of SPSS showed, size of cell, number of cell, and size of the glands were different. In this regards, we test gland size (Figure 1) and cell size (Figure 2). For studies of mean value, ANOVA variation and correlation coefficient we used SPSS software, the mean value of cell size (Figure3), between 50 replication were significant, between $15^{\circ} \mathrm{C}, 22^{\circ} \mathrm{C}$ and $29^{\circ} \mathrm{C}$. $p$ value $<0.000$, (Table $1 \& 2$ ).

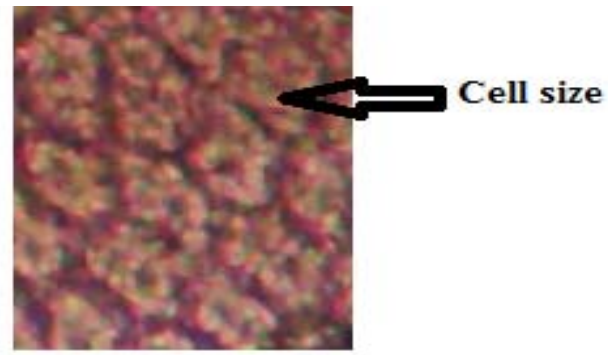

Fig. 2: The accessory gland size and cell number in Drosophila melanogaster that were different size and number cell in three temperatures (cold $<$ middle $<$ high).

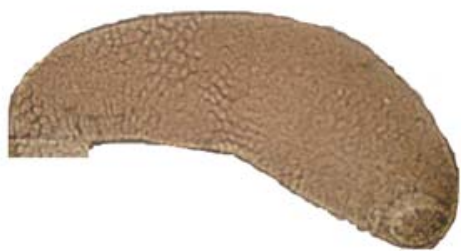

Fig. 1: The shape of accessory gland in Drosophila melanogaster. There is different size gland in temperature of $15^{\circ} \mathrm{C}$, $22^{\circ} \mathrm{C}$ and $29^{\circ} \mathrm{C} .\left(15^{\circ} \mathrm{C}<22^{\circ} \mathrm{C}<29^{\circ} \mathrm{C}\right.$. $)$

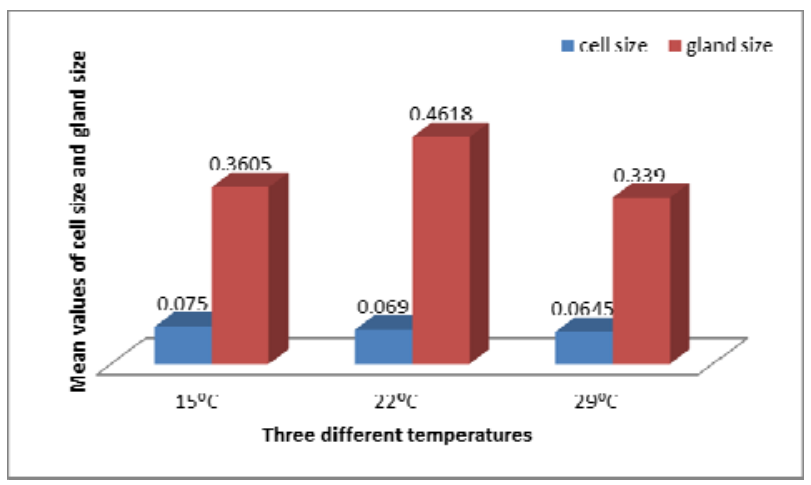

Fig. 3: The parameters of accessory gland, including cell size and gland size from left to right, also, every parameter is two graph that including, cold, middle temperature $\left(22^{\circ} \mathrm{C}\right)$ and high temperature $\left(29^{\circ} \mathrm{C}\right)$. Values are given as means $\pm \mathrm{SE}(\mathrm{N}=50)$. The length of graphs indicates the variation activity in different temperatures.

In $29^{\circ} \mathrm{C}$ mean of gland size, were bigger than $15^{\circ} \mathrm{C}$ and $22^{\circ} \mathrm{C} .\left(29^{\circ} \mathrm{C}>15^{\circ} \mathrm{C}>22^{\circ} \mathrm{C}\right)$. Results of ANOVA variation and correlation index, are shown, cold temperature in compare of middle and high temperature was significant. $p$ value $<0.000$ (Table 1,2 ). Regards cell number we counted a based layer of gland for unmated males that exposed of low, middle and high temperature. The results of mean value including, cold $>$ high $>$ middle temperature 
(Figure 4), also ANOVA analysis and correlation coefficient had done by SPSS software, the results are shown there were a positive significant between temperature and cell number from low to high temperature, $P$ value $<0.001$. (Table $1 \& 2$ )

Table 1: The accessory gland experiment including, cell number, cell size and gland size in Drosophila melanogaster. Statistical significance is based on the least significant difference is as follows; *** $\mathrm{P}<0.001$, ** $\mathrm{P}<0.01$. and $* \mathrm{P}<0.05$. The underlined numbers are insignificant records.

\begin{tabular}{|c|c|c|c|c|c|}
\hline & $\begin{array}{l}\text { Sum of } \\
\text { Squares }\end{array}$ & df & Mean Square & $\mathrm{F}$ & Sig. \\
\hline Cell number * age Between Groups & 838933.333 & 2 & 419466.667 & 2.964 & $.055^{\star}$ \\
\hline Within Groups & 2.080E7 & 147 & 141502.041 & & \\
\hline Total & 2.164E7 & 149 & & & \\
\hline Cell number * age Between Groups & .003 & 2 & .001 & .881 & 417 \\
\hline Within Groups & .245 & 147 & .002 & & \\
\hline Total & .248 & 149 & & & \\
\hline Cell number * age Between Groups & .430 & 2 & .215 & 17.973 & $.000^{\star \star}$ \\
\hline Within Groups & 1.758 & 147 & .012 & & \\
\hline Total & 2.188 & 149 & & & \\
\hline
\end{tabular}

Table 2: The correlation relationship accessory gland experiments between two temperature (middle and high) in Drosophila melanogaster. The statistical significance is based on the least significant difference is as follows; ${ }^{* * *} \mathrm{P}<0.001$, ${ }^{* *} \mathrm{P}<0.01$.and $* \mathrm{P}<0.05$. The underlined number is insignificant records.

\begin{tabular}{|c|c|c|c|c|c|c|}
\hline & & age & temperature & Cell number & Cell size & Gland size \\
\hline Age & $\begin{array}{l}\text { Pearson Correlation } \\
\text { Sig. (1-tailed) } \\
\text { N }\end{array}$ & $\begin{array}{c}1 \\
150\end{array}$ & $\begin{array}{l}1.000^{* *} \\
.000 \\
150\end{array}$ & $\begin{array}{l}.189^{*} \\
.010 \\
150\end{array}$ & $\begin{array}{l}.105 \\
100 \\
150\end{array}$ & $\begin{array}{l}.342^{* *} \\
.000 \\
150\end{array}$ \\
\hline temperature & $\begin{array}{l}\text { Pearson Correlation } \\
\text { Sig. (1-tailed) } \\
\mathrm{N}\end{array}$ & $\begin{array}{c}1.000^{* *} \\
.000 \\
150\end{array}$ & $\begin{array}{c}1 \\
150\end{array}$ & $\begin{array}{l}.189^{*} \\
.010 \\
150\end{array}$ & $\begin{array}{l}.105 \\
.100 \\
150\end{array}$ & $\begin{array}{l}.342^{* *} \\
.000 \\
150\end{array}$ \\
\hline Cell number & $\begin{array}{l}\text { Pearson Correlation } \\
\text { Sig. (1-tailed) } \\
\text { N }\end{array}$ & $\begin{array}{l}.189^{*} \\
.010 \\
150 \\
\end{array}$ & $\begin{array}{l}.189^{*} \\
.010 \\
150 \\
\end{array}$ & $\begin{array}{c}1 \\
150 \\
\end{array}$ & $\frac{.016}{1524}$ & $\frac{.121}{1509}$ \\
\hline Cell size & $\begin{array}{l}\text { Pearson Correlation } \\
\text { Sig. (1-tailed) } \\
\text { N }\end{array}$ & $\begin{array}{l}.105 \\
.100 \\
150\end{array}$ & $\begin{array}{l}.105 \\
.100 \\
150\end{array}$ & $\frac{.016}{1524}$ & $\begin{array}{c}1 \\
150 \\
\end{array}$ & $\frac{.067}{.208}$ \\
\hline Gland size & $\begin{array}{l}\text { Pearson Correlation } \\
\text { Sig. (1-tailed) } \\
\text { N }\end{array}$ & $\begin{array}{l}.342^{* *} \\
.000 \\
150 \\
\end{array}$ & $\begin{array}{l}.342^{* *} \\
.000 \\
150\end{array}$ & $\frac{.121}{1509}$ & $\frac{.067}{1508}$ & 150 \\
\hline
\end{tabular}

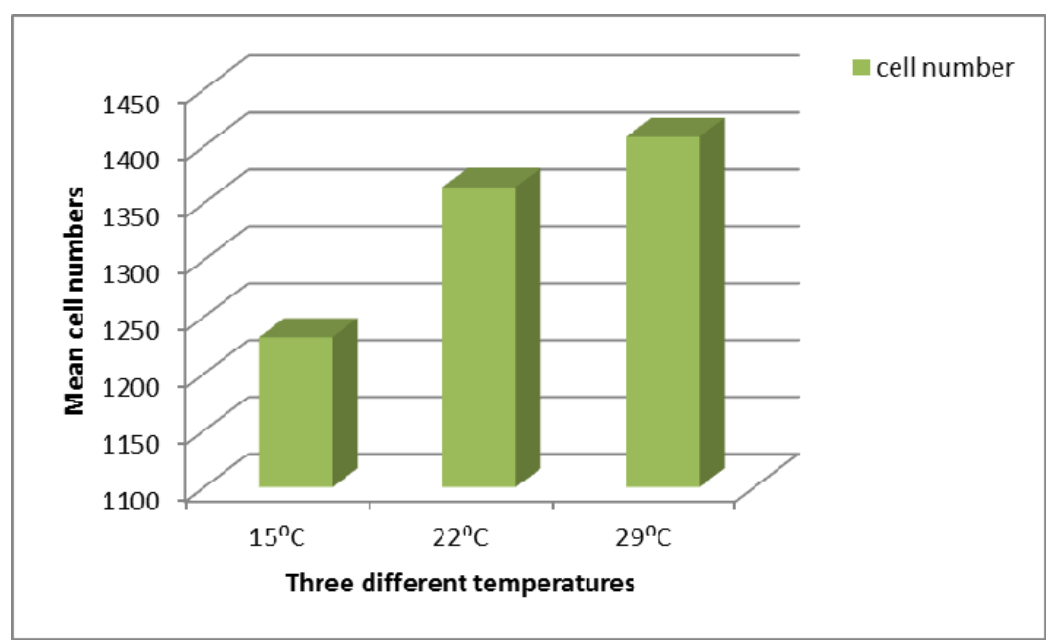

Fig. 4: The cell number of accessory gland, from left to right, also, every parameter is two graph that including, cold $\left(15^{\circ} \mathrm{C}\right)$, middle temperature $\left(22^{\circ} \mathrm{C}\right)$ and high temperature $\left(29^{\circ} \mathrm{C}\right)$. Values are given as means $\pm \mathrm{SE}(\mathrm{N}=50)$. The length of graphs indicates the variation activity in different temperatures. 


\section{DISCUSSION}

\section{The effect of high temperature on the accessory gland experiments:}

We have studied the factors that influence of the temperature on the male accessory gland. The males during mating transfer seminal proteins and peptides, along with sperm, to their mates. In Drosophila melanogaster seminal proteins are made in the male's accessory gland stimulate female's egg production and ovulation, the increase of sperm storage and survival mating in females (Wolfner, 2002, Chapman et al., 1995; Fernandez and Klowden, 1995; Kubli, 1996; Rice, 1996; Soller et al., 1997; Tram and Wolfner, 1998). There are many effects on secretions to accessory gland proteins in Drosophila melanogaster.

\section{The correlation of accessory gland experiments and temperature effect:}

In this study, we studied the effect of temperature on accessory glands that were exposed to three temperatures (low, middle and high temperatures). In the experiments the cell size, cell number and gland size, were analysed as these elements are very important in secretions in D. melanogaster. A correlation between cell size and temperature effect, in cold, middle and high condition can be made, the cell size was significantly correlated with temperature, that is in cold temperature cell size was smaller than middle and high temperature, however the gland size at high temperature was bigger than middle and low temperature respectively. Also the same situation was observed in high temperature a higher number of cell than the middle and low temperature were seen. Thus it can be inferred cell numbers and gland size are interrelated because glands of bigger size have higher cell numbers. A correlation between age, cell size, temperature, cell number and gland size a positive relationship of the level of significant cell number, $p$ value $<0.01$ and gland size the level of significant, $p$ value $<0.001$, shows that the effect of temperature on the cell number and gland size from low to high is directed, but also shows that there is no significant change in cell size due temperature. The effect of gland size on the sexual maturity, Baker et al., 2012, was studied, in C. Dalmanni stalk-eyed flies showing that, the size of accessory glands is critical to the sexual maturity. Development for sexual maturity, as well as the subsequent importance of accessory gland size in determining adult male mating frequency shows that, moreover, the reproductive gland size affects the male mating frequency (Baker et al., 2012). Studies on D. nasuta subgroup have shown that there is a strong correlation between size of glands and the quantity of proteins secreted (Ravi Ram and Ramesh, 2002). There is a relationship between number of cell, cell size of glands, and quantity secretions (Bairati, 1968; Bertram et al., 1992; Ravi Ram and Ramesh, 2003). Seven members that belong to the Drosophila nasuta subgroup, were discussed by Ravi Ram and Ramesh (2002), the results showed that in some subgroups of Drosophila that have bigger cell size and cell number the quantity of secretions were high. Showing a positive relationship between cell size, cell number and gland size with the quantity of secretary protein synthesized. Present study showed that flies that are exposed to normal temperature, between 22 to $25^{\circ} \mathrm{C}$ were normal, however at $29^{\circ} \mathrm{C}$, cell size, cell number and gland size are bigger than middle temperature $\left(22^{\circ} \mathrm{C}\right)$ but the results of fecundity and fertility in females flies was lower at the middle temperature, than high temperature however the size of gland was bigger although, the metabolism to reduced when flies are exposed to low and high temperatures. In Drosophila melanogaster, populations normal temperature is necessary for developmental and physiological processes (Feder et al., 1996; Kamping \& Van Delden, 1999; David \& Clavel, 1969; Mckenzie, 
1975; Parsons, 1978). Also it was found, the flies that were exposed to low and high temperature $\left(12\right.$ to $15^{\circ} \mathrm{C}$ and 29 to $\left.33^{\circ} \mathrm{C}\right)$ had highest mortalities and strongest karyotypic effects because of limited physiological capabilities of the organism at a temperatures that are not mated. Finally were concluded, that temperature effects the development of accessory gland elements, however the range of temperature between $15^{\circ} \mathrm{C}$ to $29^{\circ} \mathrm{C}$ only affects the glands however there are other parameters acting on the male reproductive performance and female fitness components, including male age, female egg laying and egg hatchability which can change the male reproductive performance and offspring fitness.

\section{ACKNOWLEDGMENTS}

The authors are grateful to the Chairman, Department of Studies in Zoology, University of Mysore, and Drosophila stock center , University of Mysore for providing facilities to carry out this work. This work was also financially supported by the Research Council of Islamic Azad University Tonekabon Branch, Iran.

\section{REFERENCES}

Ashburner, M. (1970). Patterns of puffing activity in the salivary gland chromosomes of Drosophila. V. Responses to environmental treatments. Chromosoma, 31:356-37.

Bertram, M., G.A. Akerker, R.L. Ard, C. Gonzalez and M.F. Wolfner. (1992). Mech. Dev. Biol., 38: 33-40.

Bairati, A. (1968). Structure and ultrastructure of the male reproductive system of Drosophila melanogaster Meig. 2. The genital duct and accessory glands. Monit Zool Ital., 2: 105-182.

Baker, R H.; Ashwell, RIS.; Richards, T.; Fowler, K.; Chapman, T. and A. Pomiankowski, (2001). Male effects on female reproductive output in the stalk eyed fly, Cyrtodiopsis dalmanni. Behav Ecol., 12:732-739.

Bangham, J., T. Chapman., L. Partridge. (2002). Effects of body size, accessory gland and testis size on pre- and postcopulatory success in Drosophila melanogaster. Anim. Behav., 64:915-921.

Chapman, T., L.F. Liddle., J.M. Kalb., M.F. Wolfner., L. Partridge. (1995). Cost of mating in Drosophila melanogaster females is mediated by male accessory gland products. Nature., 373: 241-244.

Chapman, T. and S. J. Davies. (2004). Functions and analysis of the seminal fluid proteins of male Drosophila melanogaster fruit flies. Peptides., 25: 1477-1490.

Coulthart, M. B., and R. S. Singh. (1988). Low genie variation in male-reproductivetract proteins of Drosophila melanogaster and D. simulans. Mol. Biol. Evol., 5: 167- 181.

David, J. and M. F. Clavel. (1969). Influence de la temperature sur le nombre, le nombre, le pourcentage d'eclosion et la tail le des oenfs pondus Par $D$. melanogaster. Ann. Soc. Entomol. Fr., 5: 161-177.

Feder, M. E. (1996). Ecological and evolutionary physiology of stress proteins and the stress response: The Drosophila melanogaster model. In I. A. Johnston, A. F. Bennett (Eds.), Animals and temperature: Phenotypic and evolutionary adaptation (79-102). Cambridge University Press, Cambridge, U.K. 
Fernandez, N.M., M.J. Klowden. (1995). Male accessory gland substances modify the host seeking behaviour of gravid Aedes aegypti mosquitoes. Journal of Insect Physiology., 41: 965-970.

Kalb, J., DiBenedetto, AJ. M.F. Wolfner. (1993). Probing the function of Drosophila melanogaster accessory glands by directed cell ablation. Proc Natl Acad Sci USA., 90: 8093-8097.

Kamping, A. and W. Vandelden. (1999). A long-term study on interactions between the Adh and aGpdh allozyme polymorphisms and the chromosomal inversion In (2L) $\mathrm{t}$ in a seminatural population of D. melanogaster. J. Evol. Biol., 12: 809-821.

Kubli, E. (1996). The Drosophila sex peptide: a peptide pheromone involved in reproduction. Advances in Developmental Biochemistry. 4: 99-128.

Ingman-Baker, J. and E.P.M. Candido. (1980). Proteins of the Drosophila melanogaster male reproductive system: Two dimensional gel patterns of proteins synthesized in the $\mathrm{XO}, \mathrm{XY}$, and $\mathrm{XYY}$ testis and paragonial gland and evidence that the $\mathrm{Y}$ chromosome does not code for structural sperm proteins. Biochem. Genet., 18: 809-828.

Mckenzie, J. A. (1975). The influence of low temperature on survival and reproduction in populations of Drosophila melanogaster. Aust. J. Zool., 23: 237-247.

Parsons, P. A. (1978). The effect of genotype and temperature on longevity in natural populations of Drosophila melanogaster. Experimental Gerontology., 13: 167-169.

Ravi Ram, K. and Ramesh, S. R. (2003). Male accessory gland proteins in Drosophila: a multifaceted field. Ind. J. Exp. Biol., 41: 1372-1383.

Ravi Ram, K., S.R. Ramesh. (2002). Male accessory gland secretary proteins in nasuta subgroup of Drosophila: synthetic activity of Acp. Zoological Science, 19: 513-518.

Rice, W.R. (1996). Sexually antagonistic male adaptations triggered by experimental arrest of female evolution. Nature., 381: 232-234.

Schmidt, T., E. Stumm-Zollinger and P.S. Chen. (1985). Protein metabolism of Drosophila melanogaster male accessory glands - III. stimulation of protein synthesis following copulation. Insect Biochemistry, 15: 391- 401.

Soller, M., M. Bownes., E. Kubli. (1997). Mating and sex peptide stimulate the accumulation of yolk in oocytes of Drosophila melanogaster. European Journal of Biochemistry, 243: 732-738.

Tram, U., M.F. Wolfner. (1998). Seminal fluid regulation of female sexual attractiveness in Drosophila melanogaster. In: Proceedings of the National Academy of Science U.S.A., 4051-4054.

Whalen M. and G.T. Wilson. (1986). Variation and genomic localization of genes encoding Drosophila melanogaster accessory gland proteins separated by SDSPAGE. Genetics., 114:77-92.

Wolfner, M. F. (2002). The gifts that keep on giving: physiological functions and evolutionary dynamics of male seminal proteins in Drosophila. Heredity., 88: 85-93.

Wolfner MF. (1997). Tokens of love: functions and regulation of Drosophila male accessory gland products. Insect Biochem Mol Biol., 27:179-192.

Xue, L. and M. Noll. (2000). Drosophila female sexual behavior induced by sterile males showing copulation complementation.Proc. Natl. Acad. Sci. U.S.A., 97: 3272-3275. 